\title{
SECONDARY SEED DISPERSAL OF Ricinus communis LINNAEUS (EUPHORBIACEAE) BY ANTS IN SECONDARY GROWTH VEGETATION IN MINAS GERAIS ${ }^{1}$
}

\author{
Mário Marcos do Espírito Santo²
}

\begin{abstract}
In this study, I tested the efficacy of ants as secondary seed dispersers of Ricinus communis in southeastern Brazil. In a natural population of 143 individuals, I determined the ballistic dispersal distance for 62 seeds and 100 additional seeds were experimentally offered to ants in groups of ten seeds along a transect of $50 \mathrm{~m}$. Fifty-three seeds were removed by ants, mainly by the leafcutter Atta sexdens $(90.4 \%)$. The dispersal distance by ants was high, compared to the global average $(4.38 \mathrm{~m} \pm 0.74 \mathrm{~m}$ vs. $0.96 \mathrm{~m})$, but was lower than the ballistic distance $(7.27 \mathrm{~m} \pm 0.13 \mathrm{~m})$. Ants increased the total dispersal distance $(8.66 \mathrm{~m} \pm 0.60 \mathrm{~m})$, but the main benefit for the plant was the directed dispersal, with seed deposition on the enriched soil of ant nests.
\end{abstract}

Keywords: Atta sexdens, myrmecochory, and castor bean.

\section{DISPERSÃO SECUNDÁRIA DE SEMENTES DE Ricinus communis LINNAEUS (EUPHORBIACEAE) POR FORMIGAS EM VEGETAÇÃO SECUNDÁRIA EM MINAS GERAIS}

\begin{abstract}
RESUMO - Este estudo testou a eficiência de formigas como dispersores secundários de Ricinus communis no Brasil. Em uma população natural de 143 indivíduos, a distância de dispersão balística foi determinada para 62 sementes. Além disso, 100 sementes adicionais foram oferecidas a formigas em grupos de 10, ao longo de um transecto de $50 \mathrm{~m}$. Cinqüenta e três sementes foram removidas por formigas, principalmente pela formiga-cortadeira Atta sexdens (90,4\%). A distância de dispersão por formigas foi alta se comparada à média global $(4,38 \mathrm{~m} \pm 0,74 \mathrm{~m} v \mathrm{~s} .0,96 \mathrm{~m})$, porém menor que a distância de dispersão balística $(7,27$ $m \pm 0,13 \mathrm{~m})$. As formigas aumentaram a distância de dispersão total $(8,66 \mathrm{~m} \pm 0,60 \mathrm{~m})$, mas o principal benefício para a planta foi a dispersão direcionada, com a deposição das sementes no solo enriquecido encontrado nos ninhos das formigas.
\end{abstract}

Palavras-chave: Atta sexdens, mirmecocoria e mamona.

\section{INTRODUCTION}

Seed dispersal by ants (myrmecochory) is a common and well-studied phenomenon (GÓMEZ e ESPADALER, 1998; GORB e GORB, 2003; HOWE e MIRITI, 2004). Myrmecochory occurs in over 3000 plant species from 80 families, mainly in Australia and South Africa (BEATTIE e HUGHES, 2002). Usually, the diaspore of myrmecochorous species presents an oil-rich external structure termed elaiosome (PASSOS e FERREIRA, 1996; BEATTIE e HUGHES, 2002). This structure is attractive to ants, which may transport the diaspore to the nests, where they eat only the elaiosome, discarding the intact seed in the refuse dumps (HANZAWA et al,. 1988; HUGHES e WESTOBY, 1992). There are two main advantages of myrmecochory for the plant: seed deposition inside ant nests may facilitate its germination and further establishment, since these sites are enriched by ant feces and rejected prey remnants, and aerated by their tunnels (HANZAWA et al., 1988; KEELER, 1989). Furthermore, seeds in ant nests may

\footnotetext{
${ }^{1}$ Recebido em 13.12.2006 e aceito para publicação em 18.06.2007.

${ }^{2}$ Departamento de Biologia Geral da Universidade Estadual de Montes Claros, 39401-089 Montes Claros-MG. E-mail: <mario.marcos@unimontes.br>.
} 
escape predation and fire events (CHRISTIAN e STANTON, 2004; MANZANEDA et al., 2005). For Euphorbiaceae elaiosome-bearing seeds, Leal (2003) also recorded increased seed germination through elaiosome removal. The benefit to ants is the addition of an energy-rich food item to their diet (BEATTIE e HUGHES, 2002), which may increase larval number and weight (MORALES e HEITHAUS, 1998; GAMMANS et al., 2005).

Myrmecochory is a common strategy among the Euphorbiaceae, and usually follows the ballistic dispersal (autochory) (WEBSTER, 1994; LEAL, 2003), which is the explosive dehiscence of dry fruits ejecting the seeds away from the parent plant. In this case, ants are considered as secondary dispersers, a behavior described several times for seeds of primarily vertebrate-dispersed plants (KASPARI, 1993; BÖHNING-GAESE et al., 1999; PASSOS e OLIVEIRA, 2002; 2004). In this study, the secondary seed dispersal of the castor bean by ants , Ricinus communis Linnaeus (Euphorbiaceae), was characterized in areas at initial stages of succession in southeastern Brazil. This species is a worldwidedistributed perennial shrub, 3-6 $\mathrm{m}$ in height. The highly toxic seeds are characterized by their oblong-elliptical shape and glossy, mottled black or brown and white coloration (HARDIN e ARENA, 1974). Seeds are approximately $1.3 \mathrm{~cm}$ long, and one seed is found per carpel. Fruits are 3 carpellate and explode when ripe, scattering the seeds. This species is either planted as an ornamental or considered an invasive weed in some regions. In warmer regions of the world, the plant is grown for the seeds from which castor oil is extracted (HARDIN e ARENA, 1974).

The castor bean was largely studied for its commercial use and medicinal properties (HARDIN e ARENA, 1974), but ecological studies are still lacking. In the semi-arid Northeastern Brazil, $R$. communis is largely cultivated, mainly for the production of "biodiesel" (BELTRÃO, 2004). This species is also commonly found growing in disturbed and abandoned areas, typically in early successional stages. Seeds of this species are primarily ballistically dispersed, and present a white elaiosome which is attractive to ants. Though the castor bean is considered a typical myrmecochorous plant (WEBSTER, 1994; PIZO e OLIVEIRA, 2001), studies concerning its interactions with ants are still lacking. Specifically, the following questions were asked: 1)
What ant species are effective dispersers of $R$. communis seeds? 2) What is the dispersal distance of $R$. communis seeds through myrmecochory? 3) Does seed removal by ants increase the total dispersal distance of the seeds of $R$. communis?

\section{MATERIALS AND METHODS}

This study was conducted in the Ecological Station located inside the campus of the Universidade Federal de Minas Gerais, Belo Horizonte, Brazil ( $19^{\circ} 51^{\prime} \mathrm{S}, 43^{\circ}$ $57^{\prime} \mathrm{W}$ ), at $805 \mathrm{~m}$ a.s.1. Annual average temperature in this area varies from $18^{\circ} \mathrm{C}$ to $20^{\circ} \mathrm{C}$, and the average annual precipitation is $1500 \mathrm{~mm}$. The predominant vegetation is tropical semideciduous forest. The study site was in an early stage of succession and is currently recovering from recent deforestation (approximately 2 years).

I studied a natural population of 143 individuals of $R$. communis in an area of approximately $2,100 \mathrm{~m}^{2}$ dominated by this species, during June 1996. To estimate the distance of seed ballistic dispersal, I delimited a transect of $80 \mathrm{~m} \times 6 \mathrm{~m}$ parallel to the border of plant distribution and positioned approximately $2 \mathrm{~m}$ distant from the canopy of adjacent individuals. Between 16 and 23 June, I counted the number of seeds inside the transect at one-hour intervals from 7:00 $\mathrm{h}$ to 17:00 h. Only seeds with intact elaiosomes were considered, to avoid sampling seeds already displaced by ants. I marked the position of all the seeds of $R$. communis with a nail stuck into the soil right beside them. I measured the distance from the nearest adult individual (assumed as parental) with a tape and considered it as the ballistic dispersal distance. During the study period, I constantly surveyed the seeds inside the transect and observed ant attendance. All the seeds removed by ants were followed until seed deposition. When seeds were carried into an ant nest, this place was considered the final seed deposition site. I measured the distance from the original seed spot to the point of final deposition for all removed seeds and considered it as the secondary dispersal distance by ants. I also measured the distance from the point of final deposition to the assumed parental individual and considered it as the total dispersal distance.

Additionally, I offered 100 fresh seeds (collected from ripe fruits) along a transect of $50 \mathrm{~m}$ randomly assigned in the middle of this population in June $30^{\text {th }}$. At each $5 \mathrm{~m}$ along this transect, I placed ten seeds on the ground at $7 \mathrm{~m}$ (the approximate ballistic distance) 
from the nearest adult individual of $R$. communis. I surveyed all these seeds at intervals of $15 \mathrm{~min}$, from 8:00 $\mathrm{h}$ to $16: 00 \mathrm{~h}$. I observed ant attendance to these seeds and followed the removed seeds. I measured the distance from the original point where seeds were offered to the site of final deposition, which I also considered as the secondary dispersal distance by ants. All removed seeds (both offered and found inside the first transect) were grouped and the secondary dispersal distance was compared to the ballistic distance using a two-group Student t-test. The ballistic distance was also compared to the total dispersal distance (ballistic plus myrmecochory) using a paired Student t-test. Distances were log-transformed to meet normality (ZAR, 1996). Specimens of each ant species removing the seeds or consuming the elaiosome without displacing the seeds were collected and identified. The number of individuals of $R$. communis growing in abandoned ant nests in this population was also counted.

\section{RESULTS}

Sixty-two seeds were encountered inside the transect, and the ballistic distance observed for the diaspores of $R$. communis varied from $5.2 \mathrm{~m}$ to $10.5 \mathrm{~m}$, with an average distance of $7.27 \mathrm{~m} \pm 0.13 \mathrm{~m}$ (Figure 1). Among these seeds, 13 were displaced by ants, always by individuals of the leaf-cutter Atta sexdens Linnaeus (Myrmicinae). From the 100 seeds offered, 40 were removed by ants, but these also included individuals of Camponotus rufipes Fabricius (Formicinae), Solenopsis sp. (Myrmicinae), Cephalotes sp. (Myrmicinae), and an unidentified species of Myrmicinae. Overall, 53 (32.7\%) out of 162 inspected seeds were removed by ants, and the most important ant involved in seed dispersal of $R$. communis was $A$. sexdens, which accounted for $90.4 \%$ of total seed removal. Other 43 seeds $(26.5 \%)$ were encountered by individuals of $C$. rufipes, Solenopsis sp., Cephalotes sp., and an unidentified species of Myrmicinae, but the elaoisomes of these seeds were consumed without seed displacement.

The dispersal distance by ants varied from 0.12 $\mathrm{m}$ to $17.4 \mathrm{~m}(4.38 \mathrm{~m} \pm 0.74 \mathrm{~m}, \mathrm{n}=53)$, but was usually lower than the ballistic dispersal $(\mathrm{t}=7.50, \mathrm{df}=52, \mathrm{p}$ $<0.001)$. Ants were not effective in carrying the seeds through long distances, and only 9 seeds were carried for a distance longer than the average ballistic distance (Figure 1). The total dispersal distance varied from $3.7 \mathrm{~m}$ to $20.2 \mathrm{~m}(8.66 \mathrm{~m} \pm 0.60 \mathrm{~m}, \mathrm{n}=53$; Figure 1$)$, and was higher than the ballistic distance $(\mathrm{t}=-3.02$, $\mathrm{df}=$ $52, \mathrm{p}<0.005)$.

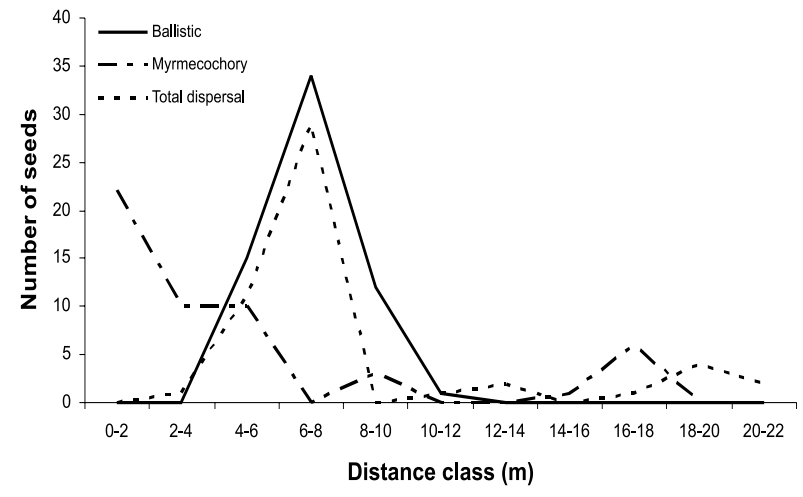

Figure 1 - Seed dispersal of Ricinus communis in secondary growth vegetation of Brazil. The ballistic curve represents the distance of each seed from the nearest adult individual (considered as parental) before ant removal. Myrmecochory represents the distance of seed removal by ants, and total dispersal represents the distance of each seed from the assumed parental individual after ant removal.

Figura 1 - Dispersão de sementes de Ricinus communis em vegetação secundária no Brasil. A curva balística representa a distância de cada semente ao indivíduo adulto mais próximo (considerado como parental) antes da remoção por formigas. Mirmecocoria representa a distância de remoção de sementes porformigas e a dipersão total representa a distância de cada semente ao indivíduo parental presumido após a remoção por formigas.

\section{DISCUSSION}

In general, the secondary dispersal by ants did not increase seed vagility of $R$. communis substantially, since the myrmecochorous dispersal distance was lower than the ballistic distance. However, these results corroborate the general trend observed for ant-dispersed seeds globally. According to Gómez e Espadaler (1998), seed dispersal curves for myrmecochores usually peak at short distances from $0 \mathrm{~m}-0.5 \mathrm{~m}$ and have long tails (up to $75 \mathrm{~m}$ ). In fact, the average ant dispersal distance in this study was much higher than the global average ( $4.38 \mathrm{~m}$ versus $0.96 \mathrm{~m}$, standard deviation not given for the global average; GÓMEZ e ESPADALER, 1998). The greater dispersal distance observed in this study reflects the fact that most seeds were dispersed by A. sexdens, a common species considered as a pest in cultivated areas (LOUREIRO e MONTEIRO, 2005). Seed dispersal by higher Attini is relatively common in Neotropical regions, especially by ants of the genera Atta and Acromyrmex (LEAL e OLIVEIRA, 1998; DALLING e WIRTH, 1999; PASSOS e OLIVEIRA, 2003; 
FARJI-BRENER e GHERMANDI, 2004; MILESI e CASENAVE, 2004; PETERNELLI et al., 2004). These large ants usually are capable of carrying seeds for long distances (PIZO et al., 2005). For instance, individuals of A. colombica (Guérin) may carry seeds as far as $100 \mathrm{~m}$ (DALLING e WIRTH, 1999). In the case of $A$. sexdens, workers always seized one seed by the elaiosome with their mandibles and carried it up to $17 \mathrm{~m}$ to the nests.

The behavior of $A$. sexdens contrasted with that observed for the other ants interacting with castor bean seeds in this study. In most cases, when a seed was found by $C$. rufipes, Solenopsis sp., Cephalotes sp., and the unidentified species of Myrmicinae, ant workers were recruited to eat the elaiosome at the same spot where the seed was encountered, a behavior called "seed cleaning" (OLIVEIRA et al., 1995). Some studies showed that species with this foraging strategy may facilitate germination by scarifying seed coat (HORVITZ, 1981; KEELER, 1989). Indeed, Leal (2003) observed that the removal of elaiosome improves seed germination of many Euphorbiaceae species because it liberates the micropyle, the structure responsible for seed imbibition. On the other hand, seed attendance by these ants may reduce seed vagility, since they do not promote seed removal and may impede the access of effective ant dispersers to the diaspore (HORVITZ e SCHEMSKE, 1986). In fact, on two occasions, workers of $A$. sexdens tried to access seeds already occupied by small Myrmicines and were expelled. Germination experiments are needed to test a beneficial effect of seed cleaning to $R$. communis.

There is indirect evidence that deposition of $R$. communis seeds on $A$. sexdens nests probably enhances germination, seedling survival and growth. From the 143 individuals of $R$. communis found in the study site, almost half ( $44.1 \%)$ were growing from inside abandoned $A$. sexdens nests. Several studies showed that ant refuses enrich the soil inside the nest or in the nest's surrounding areas, thus increasing seed germination rates, seedling survival and growth (HORVITZ, 1981; HANZAWA et al., 1988; FARJIBRENEReGHERMANI, 2004). For some myrmecochorous species, seed deposition into nests also confers protection against fire and predators (CHRISTIAN e STANTON 2004; MANZANEDA et al., 2005).

The advantage of myrmecochory to $R$. communis in this study is probably the directed dispersal, i.e., benefits determined by the specific end point of seed deposition (HOWE e MIRITI, 2004). In this case, plants would benefit from a nutrient-enriched soil for seed germination and seedling growth. Though large ants such as A. sexdens can carry seeds for several meters, distance dispersal may not be a substantial benefit of seed removal, since the increase added to the ballistic dispersal was only slight (approximately $1.5 \mathrm{~m}$ ). This mutualistic interaction may increase the establishment of $R$. communis in disturbed and abandoned areas in Brazil, accounting for its high frequency in habitats at initial stages of succession.

\section{ACKNOWLEDGEMENTS}

I am very grateful to R. P. Martins and J. E. C. Figueira, and two anonymous reviewers for their valuable suggestions on the early versions of the manuscript, to A. K. Santos for help during field work, and to A. Santos for ant identification. I also thank the staff of the Ecological Station of Universidade Federal de Minas Gerais for their kindness during the work in the reserve.

\section{REFERENCES}

BEATTIE, A. J.; HUGHES, L. Ant-plant interactions. In: HERRERA, C. M.; PELLMYR, O. (Eds). Plant-animal interactions: an evolutionary approach. New York: Blackwell Publishing, 2002. p.211-235.

Beltrẽo, N. E. M. A cadeia da mamona no Brasil, com ênfase para o segmento "Pesquisa e Desenvolvimento": estado da arte, demandas de pesquisa e ações necessárias para o desenvolvimento. Campina Grande: Embrapa, 2004. 20p. (Documentos, 129).

BÖHNING-GAESE, K.; GAESE, B. H.; RABEMANANTSOA, S. B. Importance of primary and secondary seed dispersal in the Malagasy tree Commiphora guillaumini. Ecology, v.80, p.821-832, 1999.

CHRISTIAN, C. E.; STANTON, M. L. Cryptic consequences of dispersal mutualism: Seed burial, elaiosome removal, and seed-bank dynamics. Ecology, v.85, p.1101-1110, 2004.

DALLING, J. W.; WIRTH, R. Dispersal of Miconia argentea seeds by the leaf-cutting ant Atta colombica. Journal of Tropical Ecology, v.14, p.705-710, 1999. 
FARJI-BRENER, A. G.; GHERMANDI, L. Seedling recruitment in a semi-arid Patagonian steppe: Facilitative effects of refuse dumps of leaf-cutting ants. Journal of Vegetation Sciences, v.15, p.823-830, 2004.

GAMMANS, N.; BULLOCK, J. M.; SCHÖNROGGE, $\mathrm{K}$. Ant benefits in a seed dispersal mutualism. Oecologia, v.146, p.43-49, 2005.

GÓMEZ, C.; ESPADALER, X. Myrmecochorous dispersal distances: A world survey. Journal of Biogeography, v.25, p.573-580, 1998.

GORB, E.; GORB, S. Seed dispersal by ants in a deciduous forest ecosystem: Mechanisms, strategies, adaptations. Boston: Kluwer Academic Publishers, 2003. 242p.

HANZAWA, F. M.; BEATTIE, A. J.; CULVER, D. C. Directed dispersal: Demographic analysis of an ant-seed mutualism. American Naturalist, v.131, p.1-13, 1988.

HARDIN, J. N.; ARENA, J. M. Human poisoning from native and cultivated plants. 2.ed. Durham: Duke University Press, 1974. 194p.

HORVITZ, C. C. Analysis of how ant behaviors affect germination in a tropical myrmecochore Calathea microcephala (P. and E.) Koernicke (Marantaceae): microsite selection and aril removal by Neotropical ants, Odontomachus, Pachycondyla, and Solenopsis (Formicidae). Oecologia, v.51, p.47-52, 1981.

HORVITZ, C. C.; SCHEMSKE, D. W. Seed dispersal of a neotropical myrmecochore: Variation in removal rates and dispersal distance.

Biotropica, v. 18, p.319-323, 1986.

HOWE, H. F.; MIRITI, M.N. When seed dispersal matters. Bioscience, v.54, p.651-660, 2004.

HUGHES, L.; WESTOBY, M. Effect of diaspore characteristics on removal of seeds adapted for dispersal by ants. Ecology, v.73, p.1300-1312, 1992.

KASPARI, M. Removal of seeds from neotropical frugivore feces: Ants responses to seed number. Oecologia, v.95, p.81-88, 1993.
KEELER, K. H. Ant-plant interactions. In: ABRAHAMSON, W. G. (Ed.). Plant-animal interactions. New York: McGraw-Hill, 1989. p.207-242.

LEAL, I. R.; OLIVEIRA, P. S. Interactions between fungus-growing ants (Attini), fruits and seeds in cerrado vegetation in southeast Brazil.

Biotropica, v.30, p.170-178, 1998.

LEAL, I. R. Dispersão de sementes por formigas na caatinga. In: LEAL, I. R.; TABARELLI, M.; SILVA, J. M. C. (Eds). Ecologia e conservação da caatinga. Recife: Universitaria da UFPE, 2003. p.593-624.

LOUREIRO, E. S.; MONTEIRO, A. C. Patogenicidade de isolados de três fungos entomopatogênicos a soldados de Atta sexdens sexdens (Linnaeus, 1758) (Hymenoptera: Formicidae). Revista Árvore, v.29, n.4, p.553-561, 2005.

MANZANEDA, A. J.; FEDRIANI, J. M.; REY, P. J. Adaptive advantages of myrmecochory: The predator-avoidance hypothesis tested over a wide geographic range. Ecography, v. 28, p.583-592, 2005.

MILESI, F. A.; CASENAVE, J. L. Unexpected relationships and valuable mistakes: Nonmyrmecochorous Prosopis dispersed by messy leafcutting ants in harvesting their seeds. Austral Ecology, v.29, p.558-567, 2004.

MORALES, M. A.; HEITHAUS, E. R. Food from seed-dispersal mutualism shifts sex ratios in colonies of the ant Aphaenogaster rudis. Ecology, v.79, p.734-739, 1998.

OLIVEIRA, P. S. et al. Seed cleaning by Mycocepurus goeldii ants (Attini) facilitates germination in Hymenaea courbaril (Caesalpiniaceae). Biotropica, v.27, p.518-522, 1995.

PASSOS, L.; FERREIRA, S. O. Ant dispersal of Croton priscus (Euphorbiaceae) seeds in a tropical semideciduous forest in southeastern Brazil. Biotropica, v.28, p.697-700, 1996.

PASSOS, L.; OLIVEIRA, P. S. Ants affect the distribution and performance of Clusia criuva seedlings, a primarily bird-dispersed rainforest tree. Journal of Ecology, v.90, p.517-528, 2002.

R. Árvore, Viçosa-MG, v.31, n.6, p.1013-1018, 2007 
PASSOS, L.; OLIVEIRA, P. S. Interactions between ants, fruits, and seeds in a restinga forest in south-eastern Brazil. Journal of Tropical Ecology, v.19, p.261-270, 2003.

PASSOS, L.; OLIVEIRA, P. S. Interaction between ants and fruits of Guapira opposite (Nyctaginaceae) in a Brazilian sandy plain rainforest: ant effects on seeds and seedlings. Oecologia, v.139, p.376-382, 2004.

PETERNELLI, E. F. O.; DELLA LUCIA, T. M. C.; MARTINS, S. V. Espécies de formigas que interagem com as sementes de Mabea fistulifera Mart. (Euphorbiaceae). Revista Árvore, v.28, n.5, p.733-738, 2004.
PIZO, M. A.; OLIVEIRA, P. S. Size and lipid content of non-myrmecochorous diaspores: Effects on the interaction with litter-foraging ants in the Atlantic rain forest of Brazil. Plant Ecology, v.157, p.37-52, 2001.

PIZO, M. A.; PASSOS, L.; OLIVEIRA, P. S. Ants as seed dispersers of fleshy diaspores in Brazilian Atlantic Forests. In: FORGET, P. M. et al. (Ed.).

Seed fate: Predation and secondary dispersal. Wallingford: CABI Publishing, 2005. p.315-328.

WEBSTER, G. L. Classification of the Euphorbiaceae. Annals of the Missouri Botanical Garden, v.81, p.1-32, 1994.

ZAR, J.H. Biostatistical analysis. 3.ed. Englewood Cliffs: Prentice-Hall, 1996. 662p. 